\title{
Genotypes by Environment Interaction of Faba Bean (Viciafaba L.) Grain Yield in the Highland of Bale Zone, Southeastern Ethiopia
}

\author{
Tadele Tadesse*, Behailu Mulugeta, Gashaw Sefera, Amanuel Tekalign \\ Oromia Agricultural Research Institute, Sinana Agricultural Research Center, Bale-Robe, Ethiopia
}

Email address:

tadyeko20@gmail.com (T. Tadesse), tadeleta20@yahoo.com (T. Tadesse)

${ }^{*}$ Corresponding author

To cite this article:

Tadele Tadesse, Behailu Mulugeta, Gashaw Sefera, Amanuel Tekalign. Genotypes by Environment Interaction of Faba Bean (Viciafaba L.) Grain Yield in the Highland of Bale Zone, Southeastern Ethiopia. Plant. Vol. 5, No. 1, 2017, pp. 13-17.doi: 10.11648/j.plant.20170501.13

Received: October 6, 2016; Accepted: October 19, 2016; Published: November 23, 2016

\begin{abstract}
Faba bean (Viciafaba L.) is widely cultivated in Ethiopia next to China. Faba bean (Viciafaba L.) is a partially Allogamous grain legumes grown for its high protein content in seed. The edible protein in the seed is used for human and animal consumption. The crop contributes to soil fertility through biological $\mathrm{N}$-fixation. Though it is grows in many part of the country, the national average yield is very low due to multiple factors such as limited availability of stable high yielding and disease resistant cultivar. To this end, an experiment was conducted at Sinana, Agarfa, Adaba and Sinja for two years (20132014 ) to investigate the genotype $\mathrm{x}$ environment interaction and identify stable high yielding genotypes. Fifteen genotypes including the improved and local checks were grown in RCBD. Additive main effects and multiplicative interaction (AMMI) analysis was used to estimate genotype $\mathrm{x}$ environment interaction and found to be significant $(\mathrm{P}<0.01)$. The principal components (IPCA1) and (IPCA 2) explained $52.8 \%$ and $47.2 \%$ of the interaction, respectively. Mean grain yield of genotypes ranged from 2.6t/ha to $4.2 \mathrm{t} / \mathrm{ha}$ with grand mean of 3.3t/ha. Most of the genotypes were highly responsive to the testing environment and adapted to more favorable environments. Genotype EH03014-1 and EKLS01013-1 gave higher grain yield than the checks, showed linear regression coefficient close to unity and deviation from regression close to zero. This implied that the two candidate genotypes showed stable performance across locations. Furthermore, EH03014-1 and EKLS01013-1 are resistant to major disease and showed $20.41 \%$ and $14.58 \%$ grain yield advantage over the standard check, respectively. Based on their performance across locations, stability parameters, and their yield advantage over the checks, these two genotypes were selected as candidate varieties for verification in the coming bona 2016/17 cropping season.
\end{abstract}

Keywords: Genotypes X Environment Interaction, AMMI, Stability Parameters, ASV

\section{Introduction}

Faba bean (Vciafaba L.) is one of the major pulses grown in the highlands (1800-3000m asl) of Ethiopia. Ethiopia is the second largest producer of faba bean worldwide, after the People's of Republic of China [7]. Currently, faba bean occupies, $31 \%$ of the total area cultivated for pulses in Ethiopia, with $34 \%$ of the total annual production in the country [4]. In the highland of bale zone where cereal mono cropping is the dominant practices, pulse crops like faba bean plays great role in improving soil fertility and in reducing the disease pressure developed from continuous cereal mono cropping. Furthermore this crop has high economic value with its edible seed serving as an important protein complement in the cereal based Ethiopian diet, particularly for the poor who cannot afford animal protein [7]. Also serves as a food crops and also used as cash crops in the highlands of bale zone, southeaster Ethiopia.

However the faba bean cultivars that used for production purpose by the farmers in the highlands of bale zone were low in yield, susceptible to some major faba bean diseases and gave unstable yield.

Studying involving large number of genotypes and locations provide useful information on the adaptation and stability of genotypes and also on similarities of locations [1]. Furthermore, [8] indicated that yield potential is a complex 
process which is affected by genotypes, environment and genotype $\mathrm{x}$ environment interaction. In addition, measuring a separate expression of each physiological process is not practical. Their different expressions are however, measured in total grain yield. Several statistical methods may be used to analyze and interpret grain yield performance of genotypes $\mathrm{x}$ environment interaction. However, Additive Main effects and Multiplicative Interaction (AMMI) model has been found to be more accurate in estimating yield of genotypes with in locations than unadjusted mean [3, 10]. Besides, AMMI can treat both the additive main effect and multiplicative interaction component employing the analysis of variance (ANOVA) and Interaction Principal Components (IPCA), respectively. AMMI stability value (ASV) also measures the stability of a given genotypes. It measures the distance from the genotype coordinate point to the origin from the IPCA scores of the genotypes [5]. Genotypes with the lowest ASV values are more stable than genotypes with higher ASV value. Thus, the purpose of this study is thus to apply the stability parameters on the 15 faba bean genotypes grown in eight environment and identifying varieties with high and stable yield.

\section{Material and Methods}

Twelve faba bean genotypes were evaluated against two standard one local checks under rain-fed condition for two consecutive years (2013-2014) during bona cropping season at Sinana main station, Agarfa and Adaba sub sites, and Sinja farmers' field. The experiment was conducted at each location on vertisols, texturally clay loam soil. Sinana Agricultural Research Center ( $07^{\circ} 07^{\prime} 10.837^{\prime}$ N latitude and $040^{\circ} 13^{\prime} 32.933^{\prime}$ 'E longitude; and $2400 \mathrm{~m}$ a.s.1.) is located 463 $\mathrm{km}$ south east of Addis Ababa and $33 \mathrm{~km}$ East of Robe, the capital of Bale zone. Sinja is located 50-km from Sinana and about $15 \mathrm{~km}$ from Robe in the southwest direction. Agarfa and Adaba is found at a distance of $60 \mathrm{~km}$ and $100 \mathrm{kmin}$ the south-west and west of Sinana, respectively. A Randomized complete block design with three replications was used at all locations. The plot size was $6.4 \mathrm{~m}^{2 ;}$ four rows of $40 \mathrm{~cm}$ spacing between rows and $4 \mathrm{~m}$ length. The central two rows were used for yield and other agronomic data collection $\left(3.2 \mathrm{~m}^{2}\right.$ harve stable area). The seed rate of $200 \mathrm{~kg} / \mathrm{ha}$ and the recommended fertilizer rate of $100 \mathrm{~kg} \mathrm{DAP} / \mathrm{ha}$ was used at planting. Statistical AMMI analysis of grain yield was done using CropStat7.2 computer programme [2].

Table 1. Lists of genotypes and source of the test entries.

\begin{tabular}{l|ll}
\hline codes & Genotypes & Source \\
\hline 1 & EHO3073-1 & Line developed from IBC introduction \\
2 & EK01019-7-5 & Line obtained from HARC \\
3 & EK CSR01009-2-2 & Line obtained from HARC \\
4 & EHO3021-4 & Line developed from IBC introduction \\
5 & EHO3055-2 & Line developed from IBC introduction \\
6 & EK02006-2-1 & Line obtained from HARC \\
7 & EKLS01022-1 & Line obtained from HARC \\
8 & EKLS01013-1 & Line obtained from HARC \\
9 & EH00005-6-1 & Line obtained from HARC \\
10 & EHO3043-1 & Line developed from IBC introduction \\
11 & EHO3052-3 & Line developed from IBC introduction \\
12 & EHO3029-2 & Line developed from IBC introduction \\
13 & Shallo & Released variety from SARC \\
14 & Degaga & Released variety from HARC \\
15 & Local check & Local cultivar \\
\hline
\end{tabular}

HARC $=$ Holeta Agricultural Research Center, $\mathrm{IBC}=$ Institute of Biodiversity and Conservation, $\mathrm{SARC}=$ Sinana Agricultural Research Center

\section{Result and Discussion}

The mean grain yield of genotypes across environment (year x location) ranged from 3.06 to $4.13 \mathrm{t} / \mathrm{ha}$. From all the genotypes, the local check was the lowest yielding (Table 2). The highest grain yield was obtained by genotype EH030431 followed by EKLS01013-1. These two genotypes have yield advantage of $20.41 \%$ and $14.58 \%$ over the standard check. The range for day to maturity was from 140 to 143 days. Plant height of the genotypes was ranged from 138$146 \mathrm{~cm}$ whereas thousand seed weight also ranged from 571 to $800 \mathrm{gm}$. Furthermore most of the genotypes showed moderately resistance to the major faba bean diseases (Table 4). The highest mean grain yield of the genotypes was obtained in Sinana location followed by Adaba, Sinja and Agarfa. The variation among the locations was almost similar except for Sinana (Table 3). The results indicated that specific and wide adaptations were equally important as suggested by [6].

Table 2. Mean grain yield (t/ha) of 15 faba bean genotype grown in eight environments in Southeaster Ethiopia.

\begin{tabular}{|c|c|c|c|c|c|c|c|c|c|}
\hline \multirow{2}{*}{ Genotypes } & \multicolumn{8}{|c|}{ Environments (Year X Location) (t/ha) } & \multirow{2}{*}{$\begin{array}{l}\text { Grand mean of } \\
\text { genotypes over env't }\end{array}$} \\
\hline & Adaba 2013 & Adaba 2014 & Agarfa 2013 & Agarfa 2014 & Sinja 2013 & Sinja 2014 & Sinana 2013 & Sinana 2014 & \\
\hline EHO3073-1 & 3.72 & 2.04 & 2.68 & 3.24 & 2.29 & 3.45 & 3.77 & 4.71 & $3.24(13)^{*}$ \\
\hline EK01019-7-5 & 3.91 & 3.69 & 2.27 & 2.95 & 2.36 & 3.19 & 4.05 & 4.61 & $3.38(6)$ \\
\hline EKCSR 01009 & 3.25 & 3.52 & 2.47 & 3.42 & 2.80 & 2.72 & 3.74 & 4.57 & $3.31(8)$ \\
\hline EHO3021-4 & 4.14 & 1.49 & 2.78 & 3.03 & 3.73 & 3.74 & 3.70 & 4.34 & $3.37(7)$ \\
\hline EHO3055-2 & 3.81 & 2.73 & 2.02 & 3.17 & 2.65 & 3.11 & 3.64 & 4.19 & $3.17(14)$ \\
\hline EK02006-2-1 & 3.65 & 3.07 & 2.84 & 3.03 & 2.15 & 3.22 & 3.78 & 4.53 & $3.28(10)$ \\
\hline EKLS01022-1 & 2.79 & 4.14 & 2.08 & 3.24 & 2.53 & 3.53 & 3.65 & 3.96 & $3.24(12)$ \\
\hline EKLS01013-1 & 4.23 & 4.59 & 3.11 & 3.49 & 3.49 & 3.47 & 4.11 & 4.96 & $3.93(2)$ \\
\hline EH00005-6-1 & 4.023 & 2.835 & 2.619 & 3.722 & 3.554 & 3.078 & 3.624 & 4.266 & 3.47 (3) \\
\hline EHO3043-1 & 4.13 & 4.04 & 3.57 & 4.07 & 3.68 & 4.08 & 4.42 & 5.03 & $4.13(1)$ \\
\hline EHO3052-3 & 4.02 & 3.15 & 2.83 & 3.58 & 2.76 & 2.54 & 4.28 & 4.28 & $3.43(4)$ \\
\hline EHO3029-2 & 3.52 & 2.45 & 2.89 & 3.62 & 2.35 & 2.99 & 3.65 & 4.53 & $3.25(11)$ \\
\hline Shallo & 4.23 & 1.86 & 2.88 & 3.40 & 3.16 & 3.22 & 3.99 & 4.69 & $3.43(5)$ \\
\hline
\end{tabular}




\begin{tabular}{lllllllllll}
\hline \multirow{2}{*}{ Genotypes } & \multicolumn{2}{l}{ Environments (Year X Location) (t/ha) } & \multicolumn{1}{c}{} & Grand mean of \\
& \cline { 2 - 10 } genotypes over env't \\
\hline Degaga & 3.46 & 3.29 & 2.61 & 2.99 & 2.95 & 2.81 & 3.89 & 4.32 & $3.29(9)$ \\
Local check & 2.95 & 1.67 & 2.62 & 3.77 & 2.69 & 3.16 & 3.94 & 3.66 & $3.06(15)$ \\
Mean env't & 3.72 & 2.97 & 2.69 & 3.38 & 2.88 & 3.22 & 3.88 & 4.44 & 3.40 \\
LSD5\% & 1.29 & 0.91 & 0.55 & 0.66 & 0.73 & 0.52 & 0.65 & 0.50 & 0.31 \\
CV\% & 24.00 & 21.00 & 14.00 & 14.00 & 18.00 & 11.00 & 12.00 & 8.00 & 18.30 \\
\hline
\end{tabular}

*Number in parenthesis for grand mean of grain yield indicates rank of genotypes

Table 3. Mean grain yield (t/ha) of faba bean genotypes $x$ site over two years, 2013-2014.

\begin{tabular}{|c|c|c|c|c|c|c|}
\hline Code & Genotypes & Agarfa & Sinja & Adaba & Sinana & Mean \\
\hline 10 & EHO3043-1 & 3.82 & 3.88 & 4.08 & 4.73 & 4.13 \\
\hline 8 & EKLS01013-1 & 3.30 & 3.48 & 4.41 & 4.53 & 3.93 \\
\hline 9 & EH00005-6-1 & 3.17 & 3.32 & 3.43 & 3.95 & 3.47 \\
\hline 11 & EHO3052-3 & 3.21 & 2.65 & 3.59 & 4.28 & 3.43 \\
\hline 13 & Shallo & 3.14 & 3.19 & 3.04 & 4.34 & 3.43 \\
\hline 2 & EK01019-7-5 & 2.61 & 2.78 & 3.80 & 4.33 & 3.38 \\
\hline 4 & EHO3021-4 & 2.91 & 3.74 & 2.81 & 4.02 & 3.37 \\
\hline 3 & EK CSR01009 & 2.95 & 2.76 & 3.38 & 4.16 & 3.12 \\
\hline 14 & Degaga & 2.78 & 2.88 & 3.38 & 4.10 & 3.29 \\
\hline 6 & EK02006-2-1 & 2.94 & 2.69 & 3.36 & 4.15 & 3.28 \\
\hline 12 & EHO3029-2 & 3.25 & 2.67 & 2.99 & 4.09 & 3.25 \\
\hline 7 & EKLS01022-1 & 2.66 & 3.03 & 3.47 & 3.81 & 3.24 \\
\hline 1 & EHO3073-1 & 2.96 & 2.87 & 2.88 & 4.24 & 3.24 \\
\hline 5 & EHO3055-2 & 2.60 & 2.88 & 3.27 & 3.92 & 3.17 \\
\hline 15 & Mean & 3.03 & 3.05 & 3.35 & 4.16 & 3.40 \\
\hline
\end{tabular}

Table 4. Mean performance of agronomic parameters of 15 faba bean genotypes across environment.

\begin{tabular}{|c|c|c|c|c|c|c|c|c|c|c|}
\hline \multirow{2}{*}{$\begin{array}{l}\text { Code } \\
1\end{array}$} & \multirow{2}{*}{$\begin{array}{l}\text { Genotype } \\
\text { EHO3073-1 }\end{array}$} & \multirow{2}{*}{$\begin{array}{l}\text { Days to } \\
\text { mature }\end{array}$} & \multirow{2}{*}{$\begin{array}{l}\text { Plant } \\
\text { height }(\mathbf{c m})\end{array}$} & \multirow{2}{*}{$\begin{array}{l}\text { No.pod/ } \\
\text { plant }\end{array}$} & \multirow{2}{*}{$\begin{array}{l}\text { No. } \\
\text { seed/pod }\end{array}$} & \multirow{2}{*}{$\begin{array}{l}\text { Stand\% } \\
82\end{array}$} & \multirow{2}{*}{$\begin{array}{l}\begin{array}{l}1000 \text { seed } \\
\text { weight }(\mathrm{g})\end{array} \\
694\end{array}$} & \multicolumn{3}{|c|}{$\begin{array}{l}\text { Disease score (1-9 scale) } \\
\text { Rust Ch.spt ASBL }\end{array}$} \\
\hline & & & & & & & & 6 & 5 & 3 \\
\hline 2 & EK01019-7-5 & 142 & 143 & 16 & 3 & 85 & 784 & 5 & 5 & 4 \\
\hline 3 & EK CSR01009 & 141 & 146 & 18 & 3 & 85 & 800 & 6 & 6 & 4 \\
\hline 4 & EHO3021-4 & 142 & 143 & 17 & 3 & 82 & 706 & 5 & 5 & 4 \\
\hline 5 & EHO3055-2 & 141 & 138 & 19 & 3 & 82 & 632 & 5 & 6 & 4 \\
\hline 6 & EK02006-2-1 & 143 & 143 & 17 & 3 & 85 & 747 & 5 & 5 & 5 \\
\hline 7 & EKLS01022-1 & 141 & 143 & 18 & 3 & 84 & 781 & 5 & 4 & 3 \\
\hline 8 & EKLS01013-1 & 142 & 146 & 17 & 3 & 86 & 782 & 4 & 4 & 3 \\
\hline 9 & ЕН00005-6-1 & 141 & 139 & 19 & 3 & 80 & 651 & 5 & 5 & 4 \\
\hline 10 & EHO3043-1 & 141 & 141 & 18 & 3 & 83 & 698 & 3 & 4 & 3 \\
\hline 11 & EHO3052-3 & 141 & 142 & 19 & 3 & 82 & 755 & 5 & 4 & 4 \\
\hline 12 & EHO3029-2 & 140 & 139 & 20 & 3 & 81 & 650 & 5 & 4 & 5 \\
\hline 13 & Shallo (st.check) & 141 & 138 & 19 & 3 & 78 & 575 & 4 & 5 & 4 \\
\hline 14 & Degaga (st. Check) & 141 & 143 & 21 & 3 & 83 & 571 & 4 & 5 & 5 \\
\hline \multirow[t]{4}{*}{15} & Local check & 141 & 144 & 19 & 3 & 81 & 580 & 6 & 7 & 6 \\
\hline & Mean & 141 & 142 & 18 & 3 & 83 & 694 & & & \\
\hline & LSD $5 \%$ & 2.5 & 7.1 & 25.0 & 20.8 & 8.0 & 10.4 & & & \\
\hline & CV\% & 1.75 & 4.93 & 2.59 & 0.29 & 3.26 & 35.56 & & & \\
\hline
\end{tabular}

Ch.spot $=$ chocolate spot, $\mathrm{ASBL}=$ Aschochyta blight

Table 5. Analysis of variance for the Additive Main effect and Multiplicative Interaction (AMMI) for grain yield of 15 genotypes over environment.

\begin{tabular}{lllll}
\hline Sources & Degree of freedom & Sum of Square & Mean Square & F value \\
\hline Genotypes & 14 & 4.03 & 0.288 & Proba. \\
Location & 3 & 12.63 & 4.211 \\
G X L & 42 & 3.87 & 0.092 & $0.155^{* *}$ \\
AMMI compo 1 & 16 & 2.486 & $0.077^{*}$ & 2.911 \\
AMMI compo 2 & 14 & 1.082 & 0.008 & 3.033 \\
AMMI compo 3 & 12 & 0.306 & 0.031 \\
Total & 59 & 20.54 & & \\
\hline
\end{tabular}


The analysis of variance for Additive and Multiplicative interaction effect revealed that non-significant variation among the genotypes, location and location by genotypes interaction. The result indicates that there is stable performance among the genotypes over the environments. The AMMI 1 declared $64.22 \%$ of the GxE interaction sum of squares, while the AMMI 2 and 3 accounted for $27.96 \%$ and $7.91 \%$ of the interaction, respectively. The IPCA scores of the genotypes in the AMMI analysis are an indication of the stability of a genotype over environment (Table 5). The greater the IPCA scores, either negative or positive, the more specifically adapted a genotype to certain environments. The more the IPCA scores approximate to zero $(0)$, the more stable the genotype is over all environments sampled. Since, the two IPCA score for the genotypes over environment was varying and gave different meaning, AMMI's Stability Value was calculated in order to rank genotypes in terms of yield stability using the formula suggested by [9].

It is important that not only the IPCA scores be used for stability analysis to judge whether a given genotype is stable over environments, rather the three stability parameters i.e. the mean grain yield performance of a genotype, the linear regression coefficient and the deviation from the regression of the genotypes over the environment should also be take in to consideration to conclude whether a genotype is stable or not. Accordingly genotype EHO3043-1, the highest yielding genotypes over all environments has linear regression coefficient of 0.87 which is close to one and has a value of deviation from regression of 0.01 almost zero. Furthermore this genotype has the minimum AMMI stability value, ASV (0.16) which indicates this genotype is more stable over the tested environments. The other genotypes with mean grain yield ranked second in its performance over all environments, has the linear regression coefficient value of 0.98 and deviation from regression of 0.2 (Table 6). However, genotype EKLS01013-1 though its linear regression is close to unity and the deviation from the regression is close to zero, its ASV value is 1.02 indicating that the genotype is more adapted to some of the tested location rather than across all environment. But generally the two genotypes i.e. EH030431 and EKLS01013-1gave mean seed yield higher than the checks and have linear regression and deviation in the acceptable range, the two genotypes showed stable performance in the tested genotypes. Therefore these two genotypes are more stable over all environments. From all the tested genotypes, nine of them have regression coefficient value greater than one thought they have mean grain yield performance above the grand mean. Therefore, this indicates that these genotypes are highly responsive to favorable environments and are not recommended for wide adaptation rather they can fit for specific adaptation to highly favorable environments.

Table 6. Stability parameters: Regression of seed yield ( $t / h$ a) for each variety.

\begin{tabular}{|c|c|c|c|c|c|c|c|}
\hline Code & Genotypes & Mean & Slope (bi) & MS-DEV (S2di) & IPCA1 & IPCA2 & ASV \\
\hline 1 & EHO3073-1 & 3.24 & 1.20 & 0.06 & -0.22 & 0.19 & 0.53 \\
\hline 2 & EK01019-7-5 & 3.38 & 1.47 & 0.17 & 0.52 & -0.03 & 1.19 \\
\hline 3 & EKCSR 01009 & 3.31 & 1.52 & 0.02 & 0.15 & 0.16 & 0.38 \\
\hline 4 & EHO3021-4 & 3.37 & 0.67 & 0.35 & -0.54 & -0.54 & 1.36 \\
\hline 5 & EHO3055-2 & 3.17 & 1.04 & 0.04 & 0.14 & -0.18 & 0.38 \\
\hline 6 & EK02006-2-1 & 3.28 & 1.18 & 0.03 & 0.16 & 0.21 & 0.43 \\
\hline 7 & EKLS01022-1 & 3.24 & 0.89 & 0.08 & 0.20 & -0.33 & 0.55 \\
\hline 8 & EKLS01013-1 & 3.93 & 0.98 & 0.20 & 0.46 & -0.21 & 1.07 \\
\hline 9 & EH00005-6-1 & 3.47 & 0.63 & 0.00 & -0.09 & -0.22 & 0.30 \\
\hline 10 & EHO3043-1 & 4.07 & 0.87 & 0.01 & -0.05 & -0.11 & 0.16 \\
\hline 11 & EHO3052-3 & 3.43 & 1.19 & 0.11 & 0.24 & 0.39 & 0.68 \\
\hline 12 & EHO3029-2 & 3.25 & 1.02 & 0.12 & -0.17 & 0.42 & 0.57 \\
\hline 13 & Shallo & 3.43 & 1.08 & 0.07 & -0.27 & 0.07 & 0.63 \\
\hline 14 & Degaga & 3.35 & 1.02 & 0.03 & 0.15 & -0.02 & 0.34 \\
\hline 15 & Local check & 3.06 & 0.72 & 0.36 & -0.68 & 0.20 & 1.57 \\
\hline
\end{tabular}

$\mathrm{bi}=$ linear regression coefficient (slope), MS-DEV = Deviation from the regression component of interaction, IPCA $=$ Interaction principle component axes, ASV $=$ AMMI's Stability value

The bioplt interaction graph also revealed genotype EH03043-1 was the most stable genotype as it is coordinated to the origin in the graph (fig 1). Variety, Degaga, though it is closed to the origin, it has regression coefficient value of 1.02and has mean grain yield lower than the grand mean indicates as this variety is sensitive to changing environment. 


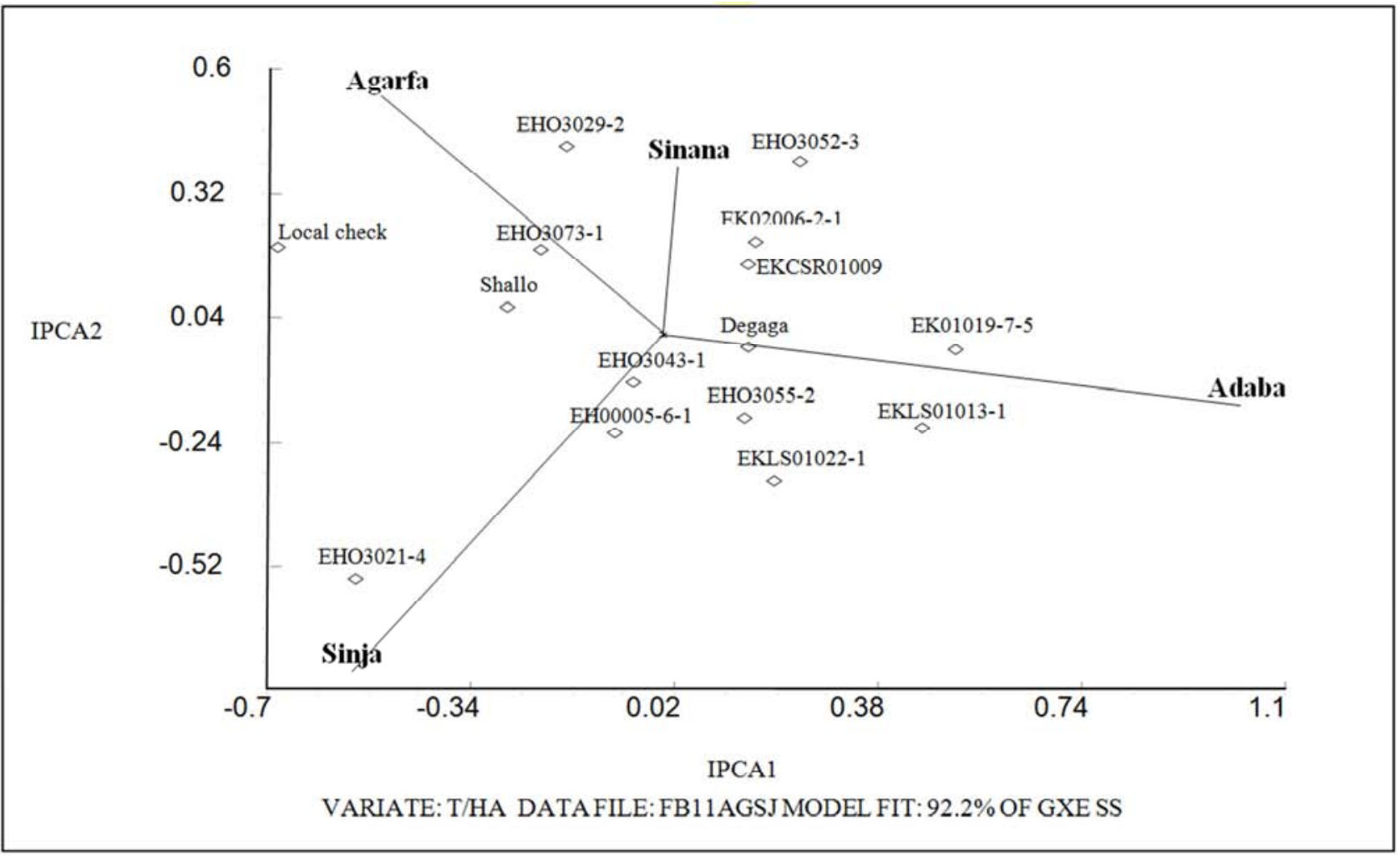

Fig. 1. Interaction biplot for the AMMI2 model.

\section{Conclusion}

The study has indicated that the AMMI model can summarize the pattern and relationship of genotypes and environments. Furthermore from the three stability indicator parameters, linear regression coefficient, mean grain yield performance of the genotypes over the environments and the deviation from the regression indicates the two genotypes, i.e. genotype number 10 and 8 are highly stable over the studied environments. Furthermore, the yield advantage over the checks, and their reaction to the major faba bean disease in the studied area, revealed that the two genotypes were identified as candidate varieties to be verified in the 2016/17 bona cropping season.

\section{References}

[1] Annicchiarico, P (1997). Joint regression versus AMMI analysis of genotype $\mathrm{x}$ environment interaction for cereals in Italy. Euphytica 94: 53-62.

[2] CropStat (2009). Crop Research Informatics Laboratory. Metro Manila, Philippines.

[3] Crossa J, Gauch HG, Zobel RW (1990). Additive main effect and multiplicative interaction analysis of two maize cultivar trials. Crop Science 30: 493-500.

[4] (CSA) Central Statistical Authority. 2013. Central Statistics Authority Report on Area Production of Major Crops Stat. Bull. Agric. Sample Survey, Volume, III Addis Ababa, Ethiopia.

[5] Gauch, H. G. and Zobel, R. W. 1996. AMMI analysis of yield trials. In: Genotype by Environment Inter-action, pp. 85-122, (Kang, M. and Gauch, H. eds). Boca Raton. CRC Press, New York.

[6] Gauch, H. G. and Zobel, R. W. 1997. identifying megaenvironments and targeting genotypes. Crop Sceince37: 311326.

[7] Mussa J, Gemechu K (2006). Vicia faba L. In: Brink M, Belay G (eds) Plant Resource of Tropical Africa 1: Cereals and Pulses, PROTA Foundation, Wageningen, Netherlands/Backhuys Publishers, Leiden, Netherlands/CTA, Wageningen, Netherlands 2006, pp. 195-199.

[8] Poehlman JM, Slepper DA (1996). Breeding Field Crops $\left(4^{\text {th }}\right.$ edition). Iowa State University Press. Ames, Iowa.

[9] Purchase JL, Hating H, Van Deventer CS(2000). Genotype x environment interaction of winter wheat (triticum aestivum L.) in South Africa II. Stability analysis of yield performance. S. Afr. J. Plant and soil.17: 101-107.

[10] Zobel, R. W., Wright, M. J., and Gauch, G. 1988. Statistical analysis of a yield trial. Agronomy Journal80: 388-393. 